\section{MINERAL METABOLISM}

STUDIES OF MNUUNOREACTIVE PARATAYROID HORMONE (IPTH) AND KALCITONIN (ICT) II JHYANTS AND CHILDREA. I.David, C.Anast, Univ. of Missouri, Pediatrics, Columbiatio. USA. Serum IPIH levels have been determined in 174 norms irildren 2 wos. to $15 \mathrm{grs}$, old and in 28 children with varions disorders of Ca and bone metaboligm. Serum IPTH Ievels in normal children were similar to those of normal adults ranging from non-detectable to $10 \mathrm{pr} \mathrm{Eq} / \mathrm{ml}$ with $75 \%$ detectable levels. Normal Ievels were found in 2 cose of osteogenesis imperfecta, in 3 Turner's syndrome, and in 3 children with renal stones.High levels of serum IPTH ( 35 to $250 \mathrm{ml} \mathrm{Eq/mI)} \mathrm{were} \mathrm{found} \mathrm{in} \mathrm{children} \mathrm{with} \mathrm{chronic} \mathrm{re-}$ nal disease and in children withhypocalcemia associated with a variety of ayndromes, including congenital obstruo tive jamdice, hemolytic uremic syndrome, glomerulonephritis,nephotic syndrome, hemorrhage and massive transfusions, salicylate intoxication, and acute leukemia. The ma jority of normal newborms as well as newborns with hypocalcemia had non-detectable to low levels of IPTH during the first 48 to $72 \mathrm{hrs}$. of 1 ife. In anather gtudy, serm ICT levele were non-detectable (<50 pg/ml $)$ in 18 normal children and in 2 children with hypercalcemia secondary to vitamin D toxicity.Non-detectable to Iow levels of ICT were found in normal zewborns and in 3 newborns with hypocalcemic tetany.Elevated serum ICT with normal serum gastrin was found in a hypocalcemic 5-week old infant following a massive intestinal resection. The significane of these resalts will be discussed.

PTH SECRETION IN EXCHANGE TRANSFUSION. RDG Milner and J.S. Woodhead, Universities of Manchester and Wales.

The citrate load in exchange transfusion (ET) performed with donor blood preserved with acidcitrate and dextrose causes a sharp fall in plasma ionized calcium(I.C. Radde et al. Ped.Res,6,43 (1972). PTH secretion during ET was studied by measuring plasma $\mathrm{PTH}, \mathrm{Ca}, \mathrm{PO}, \mathrm{citrate}$ and albumen in the donor blood and in the finfant during the procedure. Donor plasma PTH was $164 \$ 46 \mathrm{pg} / \mathrm{ml}$, significantly lower than that in the baby, $728 \pm 134 \mathrm{pg} / \mathrm{ml} \quad(\mathrm{n}=18)$. During the ET the infant's plasma PTH remained steady or rose slightly indicating increased secretion of PTH. Infants studied more than once had increasing PTH secretion with postnatal age or a high steady PTH secretion. ET caused a large net positive balance of citrate and significant negative balances of PTH,Ca and $\mathrm{PO}$.

The results show that the newborn erythroblastotic infant is able to respond to a fall in plasma ionized calcium with increased PTH secretion and that, in some infants, this response develops in early postnatal life.
STUDY OF PARATHYROID ACTIVITY IN VITAMIN D DEFICIENCY RICKETS.

M.Vainsel, TH.Manderlier, J.Corvilain,H.L.Vis. University of Brussels.

35 patients with vitamin D deficiency rickets were investigated. PTH levels were determined by radioimmunoassay.

Serum phosphate is decreased. Serum calcium is related to age. Past 15 months of life, hypocalcemia is never observed. PTH has a tendency to decrease with age. No significant correlation could be found between calcium and PTH Tevels, nor between phosphate and PTH levels. The correlation between PTH levels and aminoaciduria is poor. The subjects were divided into three groups according to calcemia and age: group I-hypocalcemic children younger than 15 months; group II- normocalcemic children younger than 15 months; group III-normocalcemic children older than 15 months. PTH levels are always high in group I and variable in groups II, III.

The parathyroid function and parathyroid responsiveness to serum calcium, in vitamin D deficiency state are discussed according to these results.

SERUM-PTH LEVELS DURING RECOVERY FROM VITAMIN DDEFICIENT RICKETS.

R. Steendijk Department of Paediatrics. University of Amsterdam.

Several years ago the author showed that adminis tration of exogenous parathyroid hormone (PTH) in a child with healing rickets did not result in hypercalcaemia before the bone lesions were no longer $\checkmark$ isible on $X$-ray examination Acta Paed.53:105, 1964 ).

A recent study in an infant with severe vitamin Ddeficient rickets revealed that the plasma-levels of endogenous PTH fell slowly during administration of vitamin D. Serum-Ca became normal in 4 weeks from the beginning of treatment. At that time PTH was still elevated and the bone lesions had not yet completely disappeared on $X-r a y$ examination. It is suggested that the presence of rachitic bone lesions require an elevated PTH-level to maintain serum-Ca within the normal range, as has also been found in dogs (Jowsey,J., J. Clin. Invest. 51:9, 1972 .
IMPORTANCE OF THE PARATHYROID IN THE BONE DEFENSE AGAINST ACIDIC DIET.P.Cuisinier-Gleizes, D. Benest, A.George, H.Mathieu. INSERM U-120,Chateau de Longchamp, Bois de Boulogne 75016 Paris-France. we stuaied the effects of acidic feeding on thyroparathyroidectomized(TPTX) rats supplemented with thyro $x$ ine \& sham-operated pair-fed(Sh.o)rats. The control groups had normal diet.Results. After 7 weeks, Mg \& $\mathrm{Na}$ in urine \& serum, serum inorganic $P$ \& alkaline phosphatases, net intestinal $C a$ absorption, were unchanged in TPTX \& Sh-op animals. In both groups, in the urine, pH was similarly decreased, $\mathrm{TA}, \mathrm{NH}, \mathrm{Ca}$ \& inorganic $\mathrm{P}$ were were similarly increased. The others parameters showed differences in tha rats fed acidic diet depen ding on ther or not they were Sh-op or TPTX.Sh-op rats showed no change in serum $C a$ or $C l$ nor in urina ry hydroxyproline or blood pH. In TPTX rats serum Ca \& urinary hydroxyproline were increased; blood pH was decreased.Histologic tibial studies evidence osteopo rosis in both experimental groups, more marked in the TPTX group.IT resulted from bone formation decreased \& bone resorption increased. But there was no increase in the osteoclasts number, rather a small decrease. These data suggest that the osteoporosis resulting from acidic diet is not parathyroid-mediated, \& that parathyroid is involved in the defense against acidosis of/by skeleton. (granted by CNRS \& CEA).
LATENT PSEUDOHYPOPARATHYROIDISM. H.Peter Kind, David K. Parkinson, Sang Whay Kooh, Donald Fraser. Dept. of Paediatrics, University of Toronto, and Research Institute, Hospital for Sick Children, Toronto, Can. 3', 5'-monophosphate (UC-AMP) in response to sion of parathyroid extract (PTE) is an accurafuindex for establishing the diagnosis of pseudohypoparathyroidism (PHP). UC-AMP after one single dose of i.v. PTE (8 u/kg) was measured in five children of two families in both of which one other member is affected with PHP. All five had normal serum calcium and phosphorus levels at the time of testing and none of them had physical signs of PHP. PTE caused a marked increase in UC-AMP in three children similar to that of controls. From two girls, tested at the age of 5 days and 13 months respectively, one did not respond to the hormone; the other showed only minimal increase in UC-AMP, identical to the amount observed in patients with PHP. Thus the inherited metabolic defect in the adenyl cyclase-cAMP system, present in PHP, can already be demonstrated in the presymptomatic state. We conclude that these two children suffer from latent pseudohypoparathyroidism and advocate that they will develop hypocalcemia later in life. 